


\section{Proficiency test for heavy metals in compound feed}

D.P.K.H. Pereboom, I.J.W. Elbers, J. de Jong, M.K. van der Lee and W.C.M. de Nijs 
Pereboom, D.P.K.H., I.J.W. Elbers, J. de Jong, M.K. van der Lee and W.C.M. de Nijs, 2016. Proficiency test for heavy metals in compound feed. Wageningen, RIKILT Wageningen University \& Research, RIKILT report 2016.015. 34 pp.; 0 fig.; 5 tab. ; 11 ref.

Project number: 1227248801-WOT

Project title: Borging private laboratoria (WOT BPL 2016 03. PT ZW)

Coordinator proficiency tests: D.P.K.H. Pereboom

Project leader: W.C.M. de Nijs

This report can be downloaded for free at http://dx.doi.org/ 10.18174/397952 or at www.wur.eu/rikilt (under RIKILT publications).

(C) 2016 RIKILT Wageningen University \& Research

The client is allowed to publish or distribute the full report to third parties. Without prior written permission from RIKILT it is not allowed to:

a) publish parts of this report;

b) use this report or title of this report in conducting legal procedures, for advertising, acquisition or other commercial purposes;

c) use the name of RIKILT other than as author of this report.

P.O. Box 230, 6700 AA Wageningen, The Netherlands, T +31(0)317 4802 56, E info.RIKILT@wur.nl, www.wur.eu/rikilt. RIKILT is part of Wageningen University \& Research.

This report from RIKILT has been produced with the utmost care. However, RIKILT does not accept liability for any claims based on the contents of this report.

RIKILT report 2016.015

Distribution list:

- Twenty-one participating laboratories. 


\section{Contents}

$\begin{array}{ll}\text { Summary } & 5\end{array}$

1

$\begin{array}{ll}\text { Introduction } & 7\end{array}$

2

$\begin{array}{ll}\text { Material and methods } & 8\end{array}$

2.1 Material preparation $\quad 8$

2.2 Sample identification $\quad 8$

2.3 Participants $\quad 8$

2.4 Material distribution and instructions 9

2.5 Homogeneity study of the test materials 9

$\begin{array}{ll}2.6 & \text { Stability of the test materials } \\ \end{array}$

$3 \quad$ Applied methods of analysis

$\begin{array}{ll}\text { Statistical evaluation } & 12\end{array}$

4.1 Calculation of the consensus value 12

4.2 Calculation of the uncertainty of the consensus value 12

4.3 Calculation of the standard deviation for proficiency assessment $\left(\sigma_{\mathrm{P}}\right) \quad 13$

$\begin{array}{lll}4.4 & \text { Performance characteristics with regard to the accuracy } & 13\end{array}$

$\begin{array}{llr}5 & \text { Results } & 16\end{array}$

5.1 Test material A $\quad 16$

$\begin{array}{ll}5.1 .1 \text { Cadmium } & 16\end{array}$

$\begin{array}{ll}5.1 .2 \text { Lead } & 16\end{array}$

$\begin{array}{lll}5.2 & \text { Test material B } & 17\end{array}$

$\begin{array}{ll}5.2 .1 \text { Cadmium } & 17\end{array}$

$\begin{array}{ll}5.2 .2 \text { Arsenic } & 17\end{array}$

$\begin{array}{llr}6 & \text { Discussion and conclusions } & 18\end{array}$

$\begin{array}{ll}\text { References } & 19\end{array}$

$\begin{array}{lll}\text { Annex } 1 & \text { Codification of the samples } & \mathbf{2 0}\end{array}$

Annex 2 Statistical evaluation of homogeneity data of test materials 21

$\begin{array}{lll}\text { Annex } 3 & \text { Instruction letter } & 23\end{array}$

$\begin{array}{lll}\text { Annex } 4 & \text { Statistical evaluation of stability data } & 24\end{array}$

Annex $5 \quad$ Overview of the applied methods $\quad 26$

$\begin{array}{lll}\text { Annex } 6 & \text { Results } & 28\end{array}$

$\begin{array}{lll}\text { Annex } 7 & \text { Overview performance per laboratory } & 32\end{array}$ 



\section{Summary}

The here described proficiency test for heavy metals in compound feed was organised by RIKILT, Wageningen UR in accordance with ISO 17043. RIKILT Wageningen UR has an ISO/IEC 17043 accreditation for proficiency tests of residues in products of animal origin. However, this specific test is not part of the accreditation. The primary goal of this proficiency test was to give laboratories the opportunity to evaluate or demonstrate their competence for the analysis of heavy metals in compound feed.

For this proficiency test, two test materials were dispatched. The heavy metal concentration in each material is given in $\mathrm{mg} / \mathrm{kg}$ with a moisture content of $12 \%$ :

- Chicken feed with a consensus value of $0.37 \mathrm{mg} / \mathrm{kg}$ cadmium and $5.2 \mathrm{mg} / \mathrm{kg}$ lead (A);

- Chicken feed with a consensus value of $0.62 \mathrm{mg} / \mathrm{kg}$ cadmium and $3.0 \mathrm{mg} / \mathrm{kg}$ arsenic (B).

The fortified materials were prepared by spiking a slurry of commercially obtained chicken compound feed, followed by extensive mixing and freeze-drying.

Homogeneity assessment showed that all materials were sufficiently homogeneous for proficiency testing. The stability test demonstrated no statistically significant loss of cadmium, lead or arsenic from the materials during the timescale of the proficiency test.

Twenty-one European laboratories participated in this proficiency test and submitted results in time. For test material A, twenty laboratories reported quantitative results and one laboratory reported a screening result for cadmium and for lead, twenty-one laboratories reported quantitative results. For test material B, twenty-one and nineteen laboratories reported quantitative results for respectively cadmium and arsenic. Two laboratories did not report quantitative results for arsenic due to the absence of the compound in their scope.

Fifteen laboratories reported details of the applied extraction method. Twelve of the fifteen laboratories applied comparable digestion methods for sample preparation and in general used ICP-MS (six laboratories) or AAS (four laboratories) for identification and quantification of the heavy metals in the materials.

The results of the proficiency test on heavy metals in feed are summarized in Table 1. Overall, 17 out of 21 participants showed optimal performance by detecting cadmium, lead and arsenic with a correct quantification/qualification in chicken compound feed.

Table 1 Summarized performance of laboratories reporting results in the proficiency test on heavy metals 2016.

\begin{tabular}{lcccc} 
Compound & \# of laboratories & FN & Used z-score & Correct results $\%$ \\
Cadmium in A & 21 & 0 & $Z_{a}$ & 100 \\
\hline Lead in A & 21 & 0 & $Z_{a}$ & 90 \\
\hline Cadmium in B & 21 & 0 & $Z_{a}$ & 100 \\
\hline Arsenic in B & 19 & 0 & $Z_{a}$ & 89 \\
\hline
\end{tabular}

1) $\mathrm{FN}=$ false negatives 


\section{Introduction}

Proficiency testing is conducted to provide laboratories with a powerful tool to evaluate and demonstrate the reliability of the data that are produced by the laboratory. Proficiency testing is an important requirement of the EU Additional Measures Directive 93/99/EEC [1] and is demanded by ISO 17025:2005 [2].

The preparation of the test materials, including the homogeneity and stability testing of the test materials, and the evaluation of the quantitative results were carried out in accordance to the guidelines of the ISO/IEC 17043 [3] accreditation of RIKILT Wageningen UR. RIKILT Wageningen UR has an ISO/IEC 17043 accreditation for proficiency tests of residues in products of animal origin. However, matrix-compound used in this Proficiency test is not part of the accreditation.

Maximum levels of the heavy metals, cadmium ( $\mathrm{Cd}$ ), arsenic ( $\mathrm{As}$ ) and lead $(\mathrm{Pb})$ are regulated in the EU in a.o. compound feed. The maximum levels (ML), as regulated in Regulation No 2002/32/EC [4] are: $0.5 \mathrm{mg} / \mathrm{kg} \mathrm{Cd}, 5 \mathrm{mg} / \mathrm{kg}$ As and $2 \mathrm{mg} / \mathrm{kg} \mathrm{Pb}$, in compound feed with a moisture content of $12 \%$.

The aim of this proficiency test was to give laboratories the opportunity to evaluate or demonstrate their competence for the analysis of heavy metals in compound feed. 


\section{Material and methods}

This proficiency test concerns the heavy metals cadmium (Cd), arsenic (As) and lead (Pb) in compound feed. The target concentrations for this test are presented in Table 1.

\subsection{Material preparation}

Commercially available chicken compound feed was used to prepare the materials A and B for the proficiency test. Each of the two materials was prepared by grinding the compound feed through a $0.5 \mathrm{~mm}$ sieve. Two kilograms of each material were mixed with three litres of water and homogenized using a blender (according to in-house standard operating procedures [5]). The slurry of either material A or B was fortified by adding a $2-3 \%$ nitric acid solution of cadmium, lead and arsenic, aiming at the levels as presented in Table 2. The fortified slurries were immediately freeze-dried, homogenized and stored at room temperature until use.

Table 2 Target added concentrations of heavy metals in the proficiency test materials.

\begin{tabular}{cccc} 
Material & \multicolumn{2}{c}{ Target concentration $(\mathrm{mg} / \mathrm{kg})$} & Arsenic \\
\cline { 2 - 4 } & Cadmium & Lead & 0 \\
\hline B & 0.25 & 5 & 3 \\
\hline
\end{tabular}

\subsection{Sample identification}

After freeze-drying and homogenization, the materials were divided into sub-portions of 15 gram and stored in polypropylene, airtight closed containers at room temperature. The samples for the participants were randomly selected and coded using a web application designed for proficiency tests (crlwebshop). The code used was Metals/2015/feed/000, in which the three digit number at the end of the code was automatically generated by the software. One sample set was prepared for each laboratory consisting of one random selected sample of each material A and B. The codes of the samples for each sample set are presented in Annex 1. For homogeneity and stability testing, 56 randomly selected containers of materials $A$ and $B$ were assigned.

\subsection{Participants}

Laboratories were asked to participate by an email sent to the laboratories present in the RIKILT Wageningen UR database and posting an announcement on the RIKILT Wageningen UR website. Twenty-one laboratories registered for the participation in the proficiency test. All of these laboratories are situated in Europe. Each participant was asked a priori, to indicate which compounds were included in the scope of their method. The participants were asked to report the results through a web application designed for proficiency tests. 


\subsection{Material distribution and instructions}

Each of the participating laboratories received a randomly assigned laboratory code, generated by the web application. The sample sets with the corresponding number, consisting of two coded samples (Annex 1 ) were sent to the participating laboratories on January $18^{\text {th }} 2016$. The sample sets were packed in a box and were dispatched at room temperature to the participants immediately by courier. The samples were accompanied by a letter describing the requested analysis (Annex 3 ) and an acknowledgement of receipt form. By e-mail the laboratories received instructions on how to use the web application to report the results.

The laboratories were asked to store the samples according to their own laboratory procedure and to analyse the samples according to their routine method. A single analysis result for cadmium, lead and arsenic in each sample was requested. The deadline for submitting the quantitative results was February $29^{\text {th }} 2016$, allowing six weeks for the analysis.

Results should be reported for cadmium, lead and arsenic as $\mathrm{mg} / \mathrm{kg}$ product with a moisture content of $12 \%$. Participants were asked to provide some information on their analytical method (extraction solvent, clean-up procedure, internal standards used, detection technique, limit of detection, limit of quantification).

\subsection{Homogeneity study of the test materials}

The homogeneity of the test materials was tested according to The International Harmonized Protocol for Proficiency Testing of Analytical Laboratories [4] and ISO 13528 [6], taking into account the insights discussed by Thompson [7] regarding the Horwitz equation. With this procedure the betweensample standard deviation $\left(\mathrm{s}_{\mathrm{s}}\right)$ and the within-sample standard deviation $\left(\mathrm{s}_{\mathrm{w}}\right)$ are compared with the standard deviation for proficiency assessment derived from the Horwitz equation $\left(\sigma_{p}, \S 4.3\right)$. The method applied for homogeneity testing is considered suitable if $\mathrm{s}_{\mathrm{w}}<0.5^{*} \sigma_{\mathrm{p}}$ and a material is considered adequately homogeneous if $\mathrm{s}_{\mathrm{s}}<0.3^{*} \sigma_{\mathrm{p}}$.

Ten containers of test materials A and B were analysed in duplicate for cadmium to determine the homogeneity of the materials. The homogeneity of the other compounds in the materials was not tested, since the homogeneity test of cadmium was considered adequate to prove sufficient homogeneity of the materials since the elements added were dissolved in one solution before spiking the matrix. The results of the homogeneity study (grand mean with the corresponding RSD) and their statistical evaluation of materials A and B are presented in Annex 2 and Table 3. Materials A and B demonstrated to be sufficiently homogeneous for use in the proficiency test.

The levels of cadmium in materials $A$ and $B$ were respectively 1.5 and 1.2 times higher than anticipated. This was due to the fact that the blank compound feed used for the preparation of the materials A and B contained traces of cadmium.

Table 3 Concentration of cadmium in materials $A$ and $B$ obtained during homogeneity testing.

\begin{tabular}{|c|c|c|}
\hline \multirow[t]{2}{*}{ Material code } & Concentration $(\mathrm{mg} / \mathrm{kg})$ & RSD ( $\%)$ \\
\hline & Cadmium & Cadmium \\
\hline A & $0.37 *$ & 1.7 \\
\hline
\end{tabular}

* Blank materials contains traces of cadmium 


\subsection{Stability of the test materials}

On January $18^{\text {th }} 2016$, the day the test materials were distributed to the participants, six randomly selected samples of each test material were stored at $<-18{ }^{\circ} \mathrm{C}$. It is assumed that the heavy metals are stable at these storage conditions. Also, six samples of each test material were stored at $4{ }^{\circ} \mathrm{C}$ and six at room temperature.

On March $4^{\text {th }} 2016,47$ days after distribution of the samples, six samples of materials $A$ and $B$ that were stored at $<-18{ }^{\circ} \mathrm{C}$, at $4^{\circ} \mathrm{C}$ and at room temperature were analysed for cadmium, lead and arsenic. For each set of test samples, the average of the results and the standard deviation were calculated.

A possible 'consequential instability' of the analytes was determined in the test materials stored at $4{ }^{\circ} \mathrm{C}$ or at room temperature $[8,6]$. A consequential instability is observed when the average value of an analyte in the test samples stored at $4{ }^{\circ} \mathrm{C}$ or stored at room temperature is more than $0.3 \sigma_{\mathrm{H}}$ below the average value of the analyte in the samples stored at $<-18{ }^{\circ} \mathrm{C}$. If so, the instability has a significant influence on the calculated z-scores. A possible statistically significant instability was determined using a Students t-test [6]. The results and statistical evaluation of the stability test are presented in Annex 4.

For cadmium, lead and arsenic in test materials $A$ and $B$, no consequential nor statistical significant difference were observed among the samples stored at $<-18^{\circ} \mathrm{C}$, the samples stored at $4{ }^{\circ} \mathrm{C}$ and the samples stored at room temperature. The compounds in the test materials are, therefore, considered stable for the duration of the study. 


\section{Applied methods of analysis}

Twenty-one laboratories carried out quantitative analyses for cadmium and lead and nineteen laboratories carried out quantitative analyses for arsenic. An overview of the information provided by the participants regarding the quantitative methods applied in this proficiency test is presented in Annex 5.

Twelve laboratories applied ICP-MS (inductively coupled plasma mass spectrometry) for the identification and quantification of the heavy metals, two laboratories applied ICP-AES (inductively coupled plasma atomic emission spectroscopy) also referred as inductively coupled plasma optical emission spectrometry (ICP-OES), five laboratories applied AAS (atomic absorption spectroscopy) of which two laboratories used the graphite furnace (GFAAS) and one laboratory used the atomization flame (FAAS). One laboratory applied ICP-HRMS (inductively coupled plasma high resolution mass spectrometry), while one laboratory did not report the detection technique.

Twelve laboratories used microwave digestion for sample preparation and therefore different acid digestion procedures were employed for the determination of elements in compound feed. Six laboratories carried out the acid digestions with a mixture of nitric acid and hydrogen peroxide to bring the sample in the form of a solution in order to introduce it into the analyzer, one laboratory used a mixture of nitric acid, hydrogen peroxide combined with hydrofluoric acid, two laboratories used only nitric acid and three laboratories used microwave digestion but without further specifications. One laboratory ashed the sample dry at $550{ }^{\circ} \mathrm{C}$ and hydrochloric acid was used as an ashing acid. One laboratory digested the sample with a mixture of nitric acid and hydrochloric acid and diluted the extract for measurement and one laboratory centrifuge and filtrate the sample without further specifications. Six laboratories provided no details on the sample preparation conditions they used.

Ten laboratories reported the use of one or more internal standards. For arsenic one laboratory used germanium as an internal standard while one laboratory used scandium. For cadmium two laboratories used indium and for lead one laboratory used bismuth and one used indium. Other labs used iridium, beryllium, rhodium, lithium, gold, yttrium and tiberium without further specifications.

One laboratory reported the use of standard addition for quantification of the elements and one laboratory used standard addition only for arsenic. 


\section{Statistical evaluation}

The statistical evaluation was carried out according to the International Harmonized Protocol for the Proficiency Testing of Analytical Laboratories [8], elaborated by ISO, IUPAC and AOAC and ISO 13528 [6] in combination with the insights published by the Analytical Methods Committee [9, 10] regarding robust statistics.

For the evaluation of the quantitative results, the consensus value, the uncertainty of the consensus value, the standard deviation for proficiency assessment and z-scores were calculated.

\subsection{Calculation of the consensus value}

The consensus value $(X)$ was determined using robust statistics $[6,9,10]$. The advantage of robust statistics is that all values are taken into account: outlying observations are retained, but given less weight. Furthermore, it is not expected to receive normally distributed data in a proficiency test. When using robust statistics, the data do not have to be normally distributed in contrast to conventional outlier elimination methods.

The robust mean of the reported results of all participants, calculated from an iterative process that starts at the median of the reported results using a cut-off value depending on the number of results, was used as the consensus value $[6,10]$.

\subsection{Calculation of the uncertainty of the consensus value}

The uncertainty of the consensus value is calculated to determine the influence of this uncertainty on the evaluation of the laboratories. A high uncertainty of the consensus value will lead to a high uncertainty of the calculated participants $z_{a}$-scores. If the uncertainty of the consensus value and thus the uncertainty of the $z_{a}$-score is high, the evaluation could indicate unsatisfactory method performance without any cause within the laboratory. In other words, illegitimate conclusions could be drawn regarding the performance of the participating laboratories from the calculated $\mathrm{z}_{\mathrm{a}}$-scores if the uncertainty of the consensus value is not taken into account.

The uncertainty of the consensus value (the robust mean) is calculated from the estimation of the standard deviation of the consensus value and the number of values used for the calculation of the consensus value [6]:

$\mathrm{u}=1.25 * \frac{\hat{\sigma}}{\sqrt{\mathrm{n}}}$

Equation I

where:

$\mathrm{u}=$ Uncertainty of the consensus value;

$\mathrm{n}=$ Number of values used to calculate the consensus value;

$\hat{\sigma}=$ The estimate of the standard deviation of the consensus value resulting from robust statistics.

According to ISO 13528 [6] the uncertainty of the consensus value (u) is negligible and therefore does not have to be included in the statistical evaluation if:

$u \leq 0.3 \sigma_{\mathrm{P}}$

Equation II 
where:

$\mathrm{u}=$ The uncertainty of the consensus value;

$\sigma_{\mathrm{p}}=$ Standard deviation for proficiency assessment (§4.3).

In case the uncertainty of the consensus value does not comply with this criterion, the uncertainty of the consensus value should be taken into account when evaluating the performance of the participants regarding the accuracy ( $\S 4.4$ ). In case the uncertainty is $>0.7 \sigma_{\mathrm{P}}$ the calculated z-scores should not be used for evaluation of laboratories performance and are presented for information only.

\subsection{Calculation of the standard deviation for proficiency assessment $\left(\sigma_{\mathrm{P}}\right)$}

According to Commission Decision 2002/657/EC [11], the coefficient of variation for the repeated analysis of a reference or fortified material under reproducibility conditions, shall not exceed the level calculated by the Horwitz equation. The Horwitz equation, $\sigma_{H}=0.02 c^{0.8495}$, presents a useful and widespread applied relation between the expected relative standard deviation of a singular analysis result under reproducibility conditions, and the concentration, c $(\mathrm{g} / \mathrm{g})$. It expresses inter-laboratory precision expected in inter-laboratory trials. Therefore, this relation is suitable for calculating the standard deviation for proficiency assessment in proficiency tests $\left(\sigma_{\mathrm{P}}\right)$.

Thompson [7] demonstrated that the Horwitz equation is not applicable to the lower concentration range $(<120 \mu \mathrm{g} / \mathrm{kg})$ as well as to the higher concentration range $(>138 \mathrm{~g} / \mathrm{kg})$. Therefore a complementary model is suggested:

For analyte concentrations $<120 \mu \mathrm{g} / \mathrm{kg}$ :

$\sigma_{\mathrm{P}}=0.22 \mathrm{c}$

Equation III

For analyte concentrations $>138 \mathrm{~g} / \mathrm{kg}$ :

$\sigma_{\mathrm{P}}=0.01 c^{0.5}$

Equation IV

where:

$\sigma_{\mathrm{P}}=$ Expected standard deviation in proficiency tests;

$c=$ Concentration of the analyte $(\mathrm{g} / \mathrm{g})$.

\subsection{Performance characteristics with regard to the accuracy}

For illustrating the performance of the participating laboratories with regard to the accuracy a $\mathrm{z}_{\mathrm{a}}$-score is calculated. For the evaluation of the performance of the laboratories, ISO 13528 [6] is applied. According to these guidelines $\mathrm{z}_{\mathrm{a}}$-scores are classified as presented in Table 4.

Table 4 Classification of $z_{a}$-scores.

$\begin{array}{cc}\left|z_{a}\right| \leq 2 & \text { Satisfactory } \\ 2<\left|z_{a}\right|<3 & \text { Questionable } \\ \left|z_{a}\right| \geq 3 & \text { Unsatisfactory }\end{array}$


If the calculated uncertainty of the consensus value complies with the criterion mentioned in $\S 4.2$, the uncertainty is negligible. In this case the accuracy z-score is calculated from:

$\mathrm{z}_{\mathrm{a}}=\frac{\mathrm{X}-\mathrm{X}}{\sigma_{\mathrm{p}}}$

Equation $\mathrm{V}$

where:

$z_{\mathrm{a}}=$ Accuracy z-score;

$\bar{x}=$ The average result of the laboratory;

$\mathrm{X}=$ Consensus value;

$\sigma_{\mathrm{P}}=$ Standard deviation for proficiency assessment.

However, if the uncertainty of the consensus value does not comply with the criterion mentioned in $\S 4.2$, it could influence the evaluation of the laboratories. Although, according to ISO 13528 in this case no z-scores can be calculated if a consensus value is used as the consensus value, we feel that evaluation of the participating laboratories is of main importance justifying the participating laboratories' effort. Therefore in this case, the uncertainty is taken into account by calculating the accuracy z-score [6]:

$z^{\prime}{ }_{a}=\frac{\bar{x}-X}{\sqrt{\sigma_{p}^{2}+u^{2}}}$

Equation VI

where:

$\mathrm{z}_{\mathrm{a}}^{\prime}=$ Accuracy $\mathrm{z}$-score taking into account the uncertainty of the consensus value;

$\bar{x}=$ The average result of the laboratory;

$X=$ Consensus value;

$\sigma_{\mathrm{P}}=$ Standard deviation for proficiency assessment;

$\mathrm{u}=$ Uncertainty of the consensus value.

If a consequential instability of the proficiency test materials is observed, this can influence the evaluation of the laboratory performance. Therefore, in that case the consequential instability is taken into account when calculating z-scores. Because instability only regards one side of the confidence interval (a decrease of the concentration) this correction only applies to the lower $2 \mathrm{~s}$ limit and results in an asymmetrical confidence interval.

In the case of a consequential instability the accuracy z-score for the laboratories that reported an amount below the consensus value is corrected for this instability by:

$z_{\mathrm{ai}}=\frac{\bar{X}-X}{\sqrt{\sigma_{p}^{2}+\Delta^{2}}}$

Equation VII

where:

$\mathrm{z}_{\mathrm{ai}}=$ Accuracy $z$-score taking into account the instability of the consensus value;

$\bar{x}=$ The average result of the laboratory;

$\mathrm{X}=$ Consensus value;

$\sigma_{\mathrm{P}}=$ Standard deviation for proficiency assessment;

$\Delta=$ Difference between average concentration of compound stored at $<-18{ }^{\circ} \mathrm{C}, 4^{\circ} \mathrm{C}$ and average concentration at room temperature.

In some cases the uncertainty of the consensus value does not comply with the criterion in $\S 4.2$ and a consequential instability is observed. In this case the $z^{\prime}{ }^{\prime}$-score for the laboratories that reported an amount below the consensus value is corrected for this instability by: 
$\mathrm{z}_{\mathrm{ai}}^{\prime}=\frac{\mathrm{X}-\mathrm{X}}{\sqrt{\sigma_{\mathrm{P}}^{2}+\Delta^{2}+\mathrm{u}^{2}}}$

Equation VIII

where:

$\mathrm{z}_{\bar{x}}^{\prime}{ }^{\prime}=$ Accuracy $z$-score taking into account the uncertainty and instability of the consensus value;

$\bar{x}=$ The average result of the laboratory;

$\mathrm{X}=$ Consensus value;

$\sigma_{\mathrm{P}}=$ Standard deviation for proficiency assessment;

$\Delta=$ Difference between average concentration of compound stored at $<-18{ }^{\circ} \mathrm{C}, 4^{\circ} \mathrm{C}$ and average concentration at room temperature;

$\mathrm{u}=$ Uncertainty of the consensus value. 


\section{$5 \quad$ Results}

Twenty-one laboratories registered for the participation in the proficiency test and all submitted the results in time. Laboratories PT814 and PT820 did not report quantitative results for arsenic due to the absence of the compound in their scope. The performance of individual laboratories is summarized in Annex 7.

All laboratories reported results for cadmium, lead and arsenic in the test material A and B. However, test material A was not fortified with arsenic and test material B was not fortified with lead. Therefore, these compounds in the respective test materials were not evaluated.

Limits of detection (LODs) reported by the participants ranged from 0.0033 to $0.163 \mathrm{mg} / \mathrm{kg}$ for cadmium, from 0.005 to $1 \mathrm{mg} / \mathrm{kg}$ for lead and from 0.002 to $0.18 \mathrm{mg} / \mathrm{kg}$ for arsenic. Levels of quantification (LOQs) reported by the participants ranged from 0.01 to $0.5 \mathrm{mg} / \mathrm{kg}$ for cadmium, from 0.017 to $3 \mathrm{mg} / \mathrm{kg}$ for lead and from 0.002 to $0.85 \mathrm{mg} / \mathrm{kg}$ for arsenic (Annex 5).

An overview of the results on the analysis of the compounds for each laboratory is presented in Annex 6.

\subsection{Test material A}

Nineteen laboratories reported results for arsenic in test material A, which was not fortified with arsenic. Traces of arsenic were detected in test material A by eleven laboratories, which varied from $0.07-0.125 \mathrm{mg} / \mathrm{kg}$. Two laboratories reported arsenic respectively $<0.1$ and $<0.3 \mathrm{mg} / \mathrm{kg}$. Two laboratories reported arsenic as detected (see Annex 6).

\subsubsection{Cadmium}

Laboratory PT814 did not quantify cadmium in material A, but they reported it as a screening result. They reported cadmium present in the sample below the LOQ of $0.5 \mathrm{mg} / \mathrm{kg}$ of their method.

Twenty laboratories reported quantitative results for cadmium. The lowest concentration reported was $0.322 \mathrm{mg} / \mathrm{kg}$ and the highest was $0.468 \mathrm{mg} / \mathrm{kg}$ (see Annex 6). The consensus value was $0.37 \mathrm{mg} / \mathrm{kg}$ with a robust standard deviation of $0.022 \mathrm{mg} / \mathrm{kg}$ (resulting in an $\mathrm{RSD}_{\mathrm{R}}$ of $6.0 \%$ ) expressing the reproducibility within this proficiency test. The robust standard deviation of $0.022 \mathrm{mg} / \mathrm{kg}$ is 3 times lower than the target standard deviation $\sigma_{\mathrm{P}}$ of $0.068 \mathrm{mg} / \mathrm{kg}$. Based on the results it is concluded that the quantification of cadmium in compound feed is reported with small ranges in this proficiency test.

The uncertainty of the consensus value was $0.006 \mathrm{mg} / \mathrm{kg}$. Since this value does not exceed $0.3 \sigma_{\mathrm{P}}$ $(0.020 \mathrm{mg} / \mathrm{kg}, \S 4.2)$, the uncertainty is not taken into account in the evaluation.

No consequential instability was observed for cadmium in the stability test during the storage period of 47 days. Therefore, the $\mathrm{z}_{\mathrm{a}}$-scores using equation $\mathrm{V}(\S 4.4)$, were calculated. With respect to the accuracy all results were satisfactory.

\subsubsection{Lead}

Twenty-one laboratories reported quantitative results for lead in material A. The lowest concentration reported was $3.45 \mathrm{mg} / \mathrm{kg}$ and the highest was $11.1 \mathrm{mg} / \mathrm{kg}$ (see Annex 6). The consensus value was $5.2 \mathrm{mg} / \mathrm{kg}$ with a robust standard deviation of $0.45 \mathrm{mg} / \mathrm{kg}$ (resulting in an $\mathrm{RSD}_{\mathrm{R}}$ of $8.6 \%$ ) expressing the reproducibility within this proficiency test. The robust standard deviation of $0.45 \mathrm{mg} / \mathrm{kg}$ is almost 1.5 times lower than the target standard deviation $\sigma_{\mathrm{P}}$ of $0.64 \mathrm{mg} / \mathrm{kg}$. Based on the results it is 
concluded that the quantification of lead in compound feed is reported with small ranges in this proficiency test.

The uncertainty of the consensus value was $0.12 \mathrm{mg} / \mathrm{kg}$. Since this value does not exceed $0.3 \sigma_{\mathrm{p}}$ $(0.193 \mathrm{mg} / \mathrm{kg}, \S 4.2)$, the uncertainty is not taken into account in the evaluation.

No consequential instability was observed for lead in the stability test during the storage period of 47 days. Therefore, the $z_{a}$-scores using equation $V(\S 4.4)$, were calculated. With respect to the accuracy, laboratory PT812 reported a questionable result and laboratory PT844 produced an unsatisfactory result.

\subsection{Test material B}

Traces of lead were detected in test material B (not fortified with lead) by thirteen laboratories, which varied from $0.06-0.354 \mathrm{mg} / \mathrm{kg}$. Two laboratories reported lead $<0.3 \mathrm{mg} / \mathrm{kg}$. Five laboratories reported lead as not detected and one laboratory as detected (see Appendix 6).

\subsubsection{Cadmium}

Twenty-one laboratories reported quantitative results for cadmium in material B. The lowest concentration reported was $0.525 \mathrm{mg} / \mathrm{kg}$ and the highest was $0.781 \mathrm{mg} / \mathrm{kg}$ (see Annex 6). The consensus value was $0.62 \mathrm{mg} / \mathrm{kg}$ with a robust standard deviation of $0.043 \mathrm{mg} / \mathrm{kg}$ (resulting in an RSDR of $6.9 \%$ ) expressing the reproducibility within this proficiency test. The robust standard deviation of $0.043 \mathrm{mg} / \mathrm{kg}$ is 2.5 times lower than the target standard deviation $\sigma_{\mathrm{p}}$ of $0.11 \mathrm{mg} / \mathrm{kg}$. Based on the results it is concluded that the quantification of cadmium in compound feed is reported with small ranges in this proficiency test.

The uncertainty of the consensus value was $0.012 \mathrm{mg} / \mathrm{kg}$. Since this value does not exceed $\sigma_{\mathrm{p}}$ $(0.032 \mathrm{mg} / \mathrm{kg}, \S 4.2)$, the uncertainty is not taken into account in the evaluation.

No consequential instability was observed for cadmium in the stability test during the storage period of 47 days. Therefore, the $z_{a}$-scores using equation $\vee(\S 4.4)$ were calculated. With respect to the accuracy all results were satisfactory.

\subsubsection{Arsenic}

Laboratories PT814 and PT820 did not report quantitative results for arsenic due to the absence of the compound from their scope.

Nineteen laboratories reported quantitative results for arsenic. The lowest concentration reported was $1.05 \mathrm{mg} / \mathrm{kg}$ and the highest was $4.10 \mathrm{mg} / \mathrm{kg}$ (see Annex 6). The consensus value was $3.0 \mathrm{mg} / \mathrm{kg}$ with a robust standard deviation of $0.31 \mathrm{mg} / \mathrm{kg}$ (resulting in an RSDR of $10 \%$ ) expressing the reproducibility within this proficiency test. The robust standard deviation of $0.31 \mathrm{mg} / \mathrm{kg}$ is almost 1.3 times lower than the target standard deviation $\sigma_{\mathrm{p}}$ of $0.41 \mathrm{mg} / \mathrm{kg}$. Based on the results it is concluded that the quantification of arsenic in compound feed is reported with small ranges in this proficiency test.

The uncertainty of the consensus value was $0.087 \mathrm{mg} / \mathrm{kg}$. Since this value does not exceed $0.3 \sigma_{\mathrm{p}}$ $(0.122 \mathrm{mg} / \mathrm{kg}, \S 4.2)$, the uncertainty is not taken into account in the evaluation.

No consequential instability was observed for arsenic in the stability test during storage period of 47 days. Therefore, the $z_{a}$-scores using equation $V(\S 4.4)$ were calculated. With respect to the accuracy, laboratory PT818 reported a questionable result and laboratory PT816 produced an unsatisfactory result. 


\section{Discussion and conclusions}

Twenty-one laboratories reported results for the proficiency test on heavy metals in two compound feed samples. The aim of this proficiency test was to give laboratories the possibility to evaluate or demonstrate their competence for the analysis of heavy metals in compound feed. Each participant was asked to indicate a priori which compounds were included in their scope. This allowed the evaluation of the results which regard to the laboratories' scope.

Two materials were sent to the participants. Cadmium, lead and arsenic were homogeneously distributed in the materials. An overview of each participant's performance is shown in Annex 7 and a summary of the results is presented in Table 5 .

Table 5 Summarized performance of laboratories reporting results in the proficiency test on heavy metals 2016.

\begin{tabular}{lcccc} 
Compound & \# of laboratories & $F^{1)}$ & Used z-score & Correct results \% \\
Cadmium in A & 21 & 0 & $Z_{a}$ & 100 \\
\hline Lead in A & 21 & 0 & $Z_{a}$ & 90 \\
\hline Cadmium in B & 21 & 0 & $Z_{a}$ & 100 \\
\hline Arsenic in B & 19 & 0 & $Z_{a}$ & 89
\end{tabular}

1) $\mathrm{FN}=$ false negatives

Of the 21 laboratories that applied a quantitative confirmatory method, seventeen laboratories showed optimal performance by detecting all compounds with sufficient sensitivity, a correct quantification of cadmium, lead and arsenic in the test materials $A$ and $B$ and the absence of false positive and false negative results.

Four laboratories reported questionable or unsatisfactory results. One laboratory reported a correct screening result for the analyte cadmium that was below the LOQ of their method. Two laboratories did not report quantitative results for arsenic due to the absence of the compound in their scope.

Based on the results of this proficiency test it was concluded that:

- None of the laboratories reported false negative results;

- All 21 laboratories showed satisfactory results for the analysis of cadmium in compound feed materials A and B (resp. consensus value of $0.37 \mathrm{mg} / \mathrm{kg}$ and $0.62 \mathrm{mg} / \mathrm{kg}$ );

- Nineteen out of 21 laboratories showed satisfactory quantitative results $(90 \%)$ for lead in test material A (consensus value of $5.2 \mathrm{mg} / \mathrm{kg}$ );

- Seventeen out of 19 laboratories showed satisfactory quantitative results (89\%) for arsenic in test material B (consensus value of $3.0 \mathrm{mg} / \mathrm{kg}$ );

- The laboratories applied similar digestion methods for the analysis of the heavy metals, in general using a microwave and the quantitative analysis are mostly performed with ICP-MS and AAS;

- There is a large range regarding the LOQs, varying from 0.01 to $0.5 \mathrm{mg} / \mathrm{kg}$ for cadmium, from 0.017 to $3 \mathrm{mg} / \mathrm{kg}$ for lead and from 0.002 to $0.85 \mathrm{mg} / \mathrm{kg}$ for arsenic 


\section{References}

1 Council directive 93/99/EEC of 29 October 1993 on the subject of additional measures concerning the official control of foodstuffs. Official Journal L 290, 24/11/1993, 0014 - 0017.

2 ISO/IEC 17025:2005(E). 2005. General Requirements for the Competence of Calibration and Testing Laboratories.

3 ISO/IEC 17043:2010. 2010. Conformity assessment - General requirements for proficiency testing.

4 Directive 2002/32/EC of the European Parliament and the council of 7 May 2002.

5 SOPA0989 - De bereiding van referentiematerialen en referentiemonsters - RIKILT.

6 ISO 13528:2015, IDT. 2015. Statistical methods for use in proficiency testing by inter-laboratory comparison, 1st edition.

7 Thompson M. 2000. Recent trends in inter-laboratory precision at $\mu \mathrm{g} / \mathrm{kg}$ and sub- $\mu \mathrm{g} / \mathrm{kg}$ concentrations in relation to fitness for purpose criteria in proficiency testing. Analyst. 125: 385-386.

8 Thompson M, Ellison SL, Wood R. 2006. The International Harmonized Protocol for the Proficiency Testing of Analytical Chemistry Laboratories. Pure Appl. Chem. 78(1):145-196.

9 Analytical Methods Committee. 1989. Robust statistics - How not to reject outliers Part 1. Basic concepts. Analyst 114:1693-1697.

10 Analytical Methods Committee. 1989. Robust statistics - How not to reject outliers Part 2. Interlaboratory trials. Analyst. 114:1699-1702.

11 Commission Decision 2002/657/EC. 12 August 2002. Implementing Council Directive 96/23/EC concerning the performance of analytical methods and the interpretation of results. Official Journal. L 221:67A-76A. 


\section{Annex 1 Codification of the samples}

\begin{tabular}{|c|c|c|}
\hline Laboratory code & $\mathbf{A}^{*}$ & B* \\
\hline PT735 & 396 & 264 \\
\hline PT808 & 840 & 705 \\
\hline PT811 & 851 & 519 \\
\hline PT812 & 458 & 167 \\
\hline PT814 & 997 & 120 \\
\hline PT815 & 854 & 957 \\
\hline PT816 & 546 & 172 \\
\hline PT817 & 588 & 416 \\
\hline PT821 & 531 & 147 \\
\hline PT838 & 206 & 464 \\
\hline PT839 & 171 & 221 \\
\hline PT840 & 679 & 381 \\
\hline PT841 & 735 & 403 \\
\hline PT842 & 184 & 606 \\
\hline PT843 & 623 & 449 \\
\hline PT844 & 173 & 399 \\
\hline
\end{tabular}

* All sample codes start with Metals/2015/Feed/ 


\section{Annex 2 Statistical evaluation of homogeneity data of test materials}

Statistical evaluation of homogeneity data of test material A for cadmium.

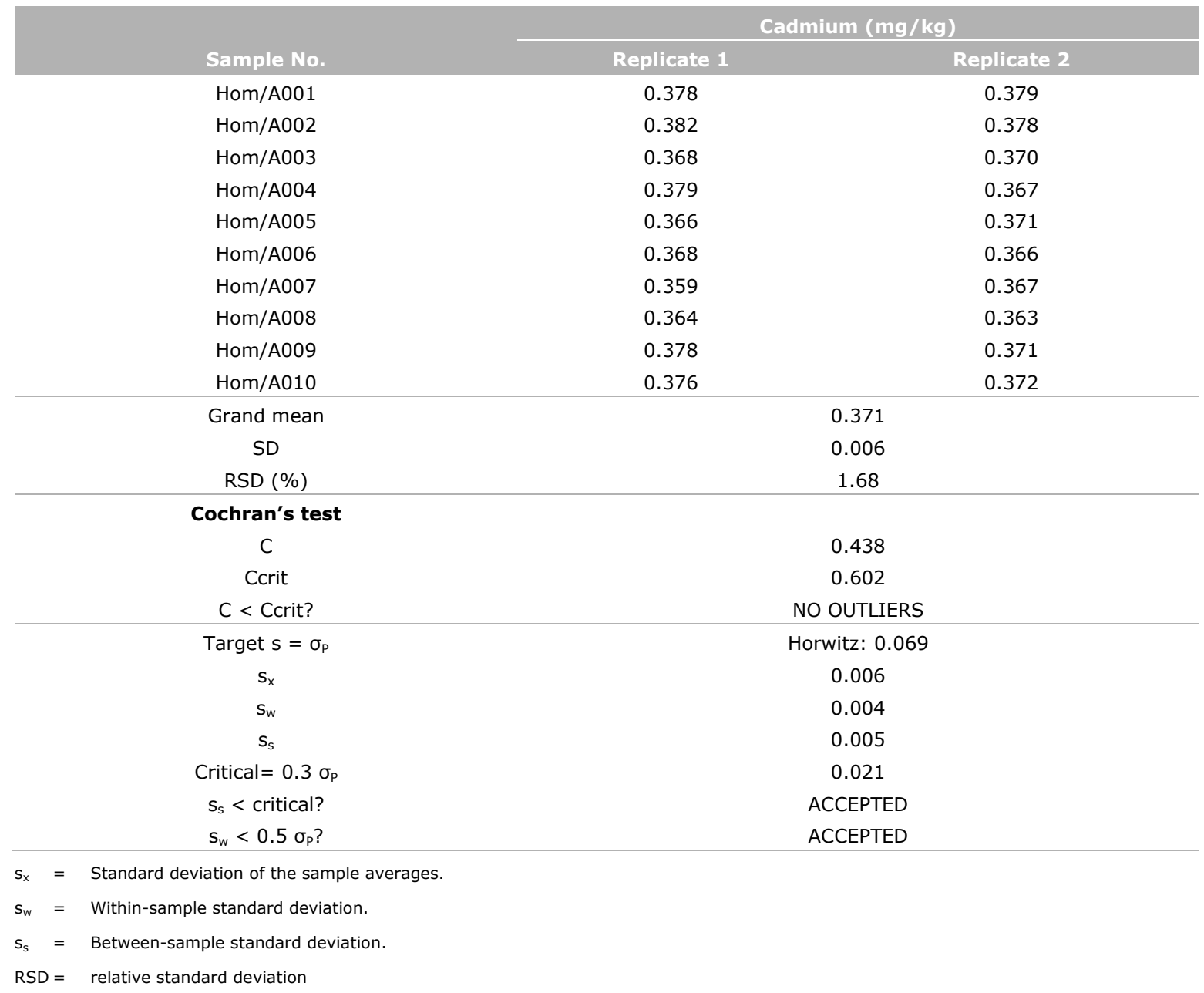


Statistical evaluation of homogeneity data of test material B for cadmium.

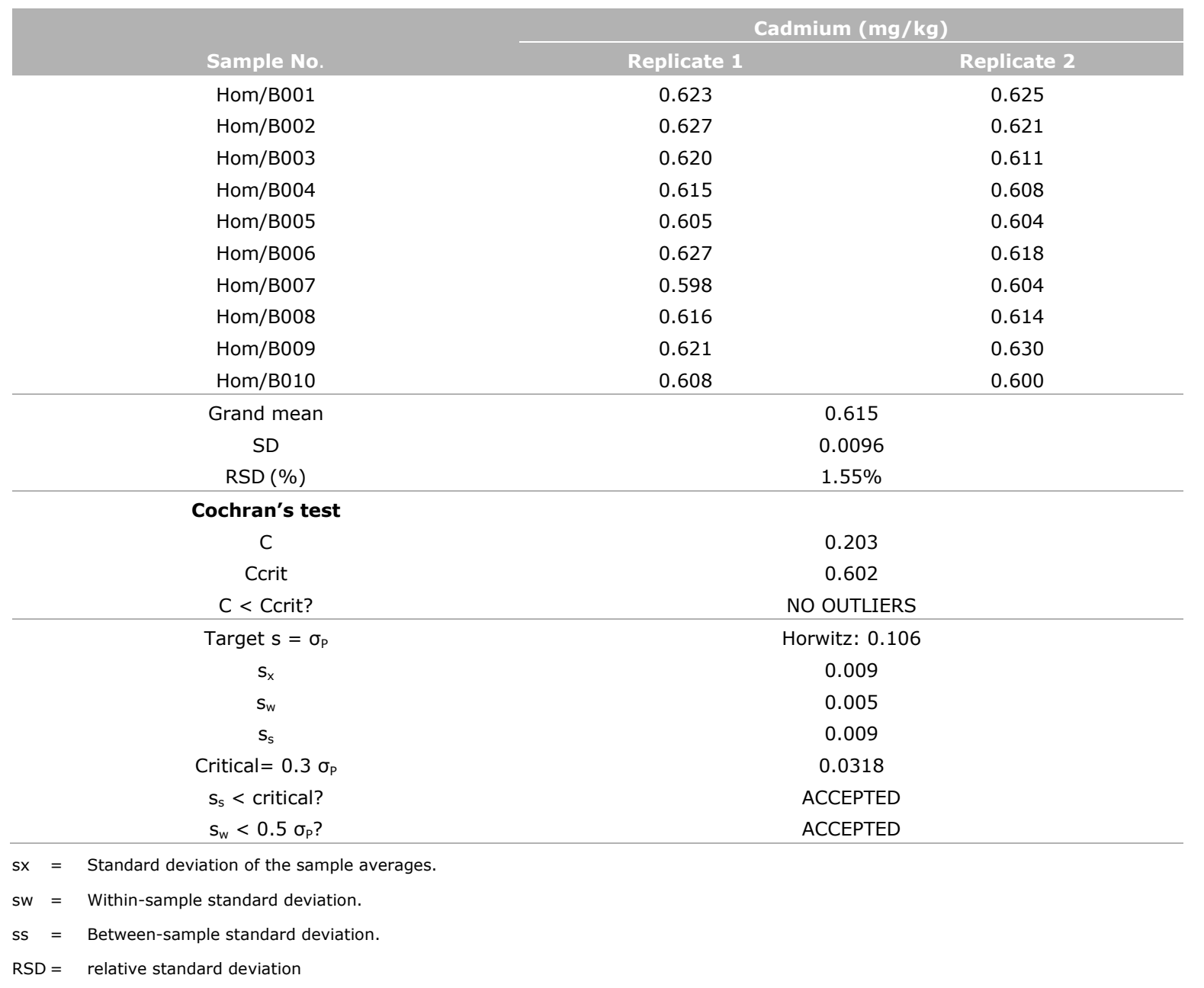




\section{Annex 3 Instruction letter}

\section{RIKILT}

Dear participant,

Thank you very much for your interest in the proficiency study for the analysis of heavy metals in compound feed. Hereby I send you a parcel containing two samples for RIKILT PT. Each sample consists of approximately 15 grams of test material. The samples may contain cadmium, lead and arsenic.

Please fill out the accompanied 'acknowledgement of receipt form' and return it immediately upon receipt of the samples, preferably by e-mail (pt.rikilt@wur.nl).

Instructions:

- After arrival store the samples according to your laboratory's procedures and treat the test material as if it was a sample for routine analysis.

- Determine the level of $\mathrm{Cd}, \mathrm{Pb}$, and As present in the test material, carry out a single analysis for each sample.

- The deadline for submitting test-results for this test is February 29th 2016.

- Please use the web application for entering your results: https://crlwebshop.wur.nl/apex/f?p=307:LOGIN.

Report all results relative to a feed with a moisture content of $12 \%$.

- Your username is:

- Your password is:

Your lab code to enter this proficiency test is:

- Please inform us about your applied method and detection technique (preferably via the web application).

Please contact me if you have any questions or need any assistance.

With kind regards,

$$
\text { D. Pereloom }
$$

D.P.K.H. Pereboom - de Fauw pt.rikilt@wur.nl

January 14, 2016

wavect

Pronciency test hesvy metals in coumpound feed

ackeranos

$15 /$ RIK0520

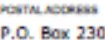

6700 AE WAGENINGEN

The Netherlands

Waftoser noches:

Wageningen Campus

sulding 123

Abkermas WBSOS 2 WAGENINGEN

mese:

www.wageningenUR ny/rikat

09098104

D.P.K.H. Pereboom - de Fauw

Tremosis

$+31(0) 317480355$

sent:

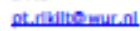

Wajeringen UR (Wegeringen Univeraty and varisos researst

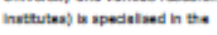
domain of thevethy food and twing envirarment.

Rucatr, part of Wegenispen UR, carrise out research into the suffety. quarity and tewth of food and faed and provides consutiancy services to (inter)inutional govermmental authortien. RDCLT is 15017025 and $1501700 \mathrm{~s}$ accredted the ccredted terta are decrited on

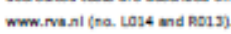




\section{Annex 4 Statistical evaluation of stability data}

Statistical evaluation for cadmium in test material $A$.

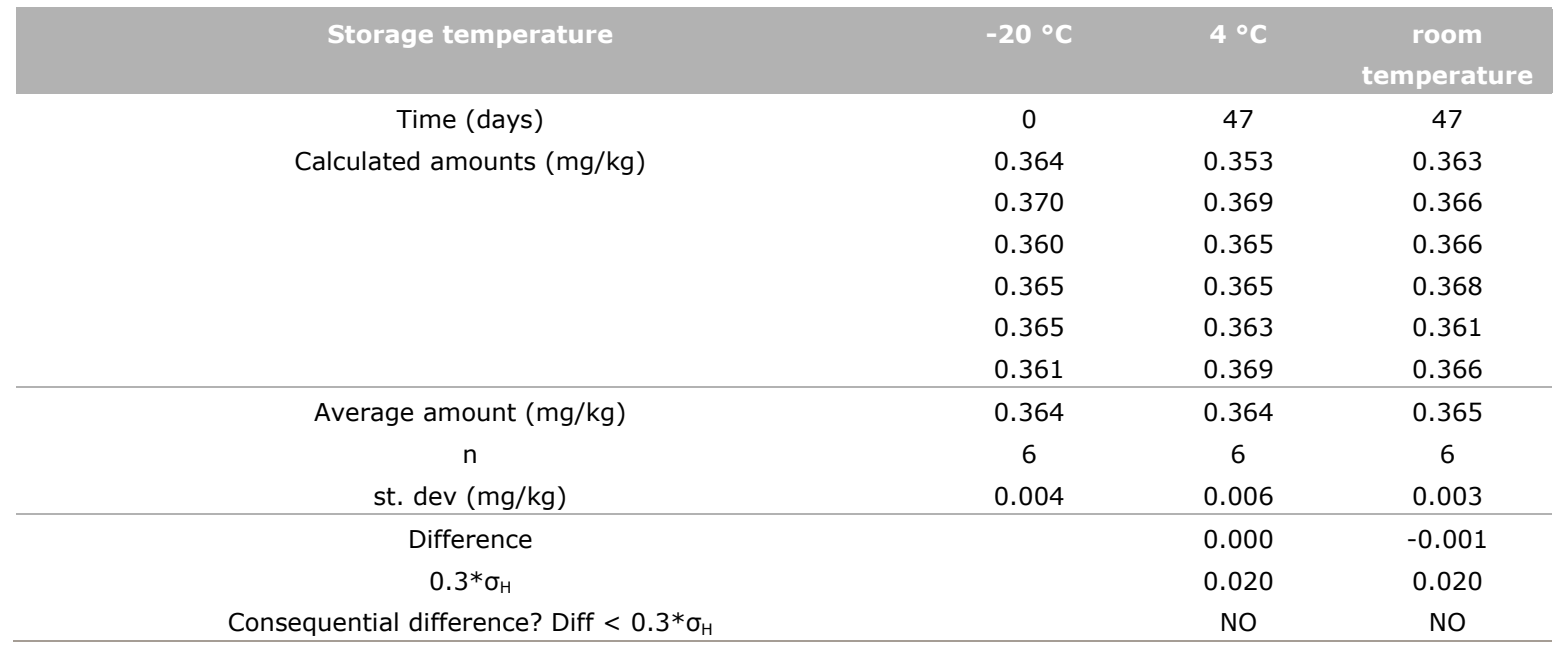

Statistical evaluation for lead in test material A.

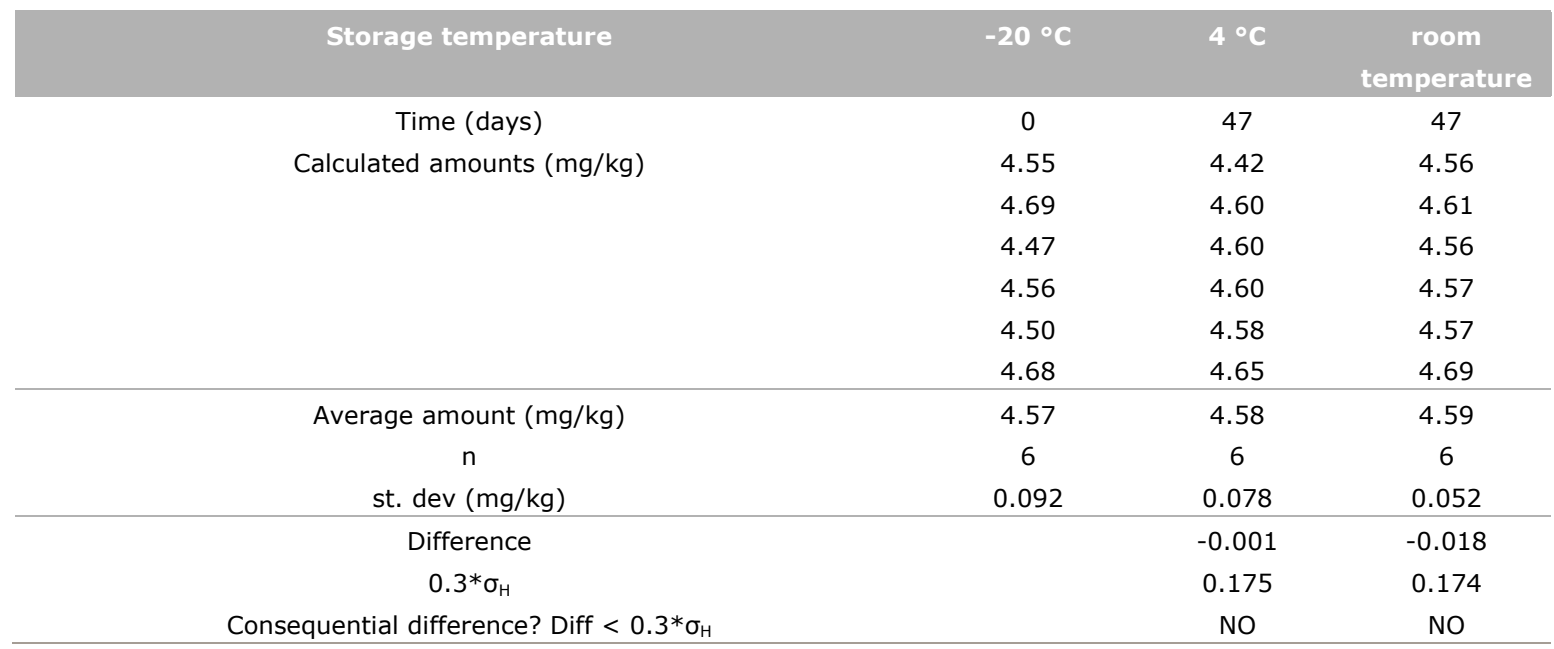


Statistical evaluation for cadmium in test material $B$.

\begin{tabular}{|c|c|c|c|}
\hline Storage temperature & $-20^{\circ} \mathrm{C}$ & $4^{\circ} \mathrm{C}$ & $\begin{array}{c}\text { room } \\
\text { temperature }\end{array}$ \\
\hline Time (days) & 0 & 47 & 47 \\
\hline \multirow{4}{*}{ Calculated amounts (mg/kg) } & 0.623 & 0.613 & 0.630 \\
\hline & 0.636 & 0.616 & 0.621 \\
\hline & 0.603 & 0.632 & 0.636 \\
\hline & 0.617 & 0.625 & 0.617 \\
\hline Average amount $(\mathrm{mg} / \mathrm{kg})$ & 0.621 & 0.623 & 0.622 \\
\hline $\mathrm{n}$ & 6 & 6 & 6 \\
\hline st. dev $(\mathrm{mg} / \mathrm{kg})$ & 0.012 & 0.009 & 0.011 \\
\hline
\end{tabular}

Statistical evaluation for arsenic in test material B.

\begin{tabular}{|c|c|c|c|}
\hline Storage temperature & $-20^{\circ} \mathrm{C}$ & $4^{\circ} \mathrm{C}$ & $\begin{array}{l}\text { room } \\
\text { temperature }\end{array}$ \\
\hline Time (days) & 0 & 47 & 47 \\
\hline \multirow{3}{*}{ Calculated amounts (mg/kg) } & 2.70 & 2.61 & 2.69 \\
\hline & 2.66 & 2.67 & 2.64 \\
\hline & 2.60 & 2.63 & 2.67 \\
\hline Average amount $(\mathrm{mg} / \mathrm{kg})$ & 2.65 & 2.65 & 2.65 \\
\hline $\mathrm{n}$ & 6 & 6 & 6 \\
\hline st. dev (mg/kg) & 0.046 & 0.049 & 0.043 \\
\hline
\end{tabular}




\section{Annex 5 Overview of the applied methods}

\begin{tabular}{|c|c|c|c|c|c|c|c|c|c|}
\hline \multirow[t]{2}{*}{ Lab } & \multirow[t]{2}{*}{ Destruction } & \multirow[t]{2}{*}{ Internal standard } & \multicolumn{3}{|c|}{ LOD (mg/kg) } & \multicolumn{3}{|c|}{ LOQ (mg/kg) } & \multirow[t]{2}{*}{ Detection method } \\
\hline & & & As & $\mathrm{Cd}$ & $\mathrm{Pb}$ & As & Cd & $\mathrm{Pb}$ & \\
\hline PT735 & Microwave digestion $\mathrm{HNO} 3+\mathrm{H} 2 \mathrm{O} 2$, none clean-up & None & & & & 0.6 & 0.06 & 0.4 & GFAAS \\
\hline PT808 & Microwave digestion $0.5 \mathrm{~g} / 50 \mathrm{ml}+\mathrm{HNO} 3$ and $\mathrm{H} 2 \mathrm{O} 2$ & $\begin{array}{l}\text { External calibration } \\
\text { and spike correction }\end{array}$ & & & & 0.3 & 0.1 & 0.3 & $\begin{array}{l}\text { Inductively coupled plasma -Atomic Emission } \\
\text { Spectrometer ICP-AES }\end{array}$ \\
\hline PT810 & Desintegration with conc $\mathrm{HNO}_{3}$ in microwave system & & & & & 0.1 & 0.01 & 0.1 & ICP-HRMS \\
\hline PT811 & Micowave destruction & & & & & 0.02 & 0.02 & 0.1 & ICP-MS \\
\hline PT812 & Closed microwave digestion $\left(\mathrm{HNO}_{3}+\mathrm{H} 2 \mathrm{O} 2\right)$ & $\begin{array}{l}\text { Standard addition for } \\
\text { As determination and } \\
\text { external calibration for } \\
\mathrm{Pb}, \mathrm{Cd} \text {. }\end{array}$ & 0.067 & 0.0033 & 0.01 & 0.2 & 0.01 & 0.03 & AAS \\
\hline PT813 & Microwave digestion with $\mathrm{HNO} 3+\mathrm{H} 2 \mathrm{O} 2+\mathrm{HF}$ & & 0.18 & 0.075 & 0.5 & 0.85 & 0.25 & 1.8 & AAS with standard addition method of calibration \\
\hline PT814 & not applied & not applied & & 0.163 & 1 & & 0.5 & 3 & FAAS \\
\hline PT815 & $\begin{array}{l}\text { Mineralisation in open microwave, digestion mixture } \\
\mathrm{H} 2 \mathrm{O} 2+\mathrm{HNO} 3,0.5 \mathrm{~g} \text { of sample, final volume } 25 \mathrm{ml}\end{array}$ & $\begin{array}{l}\text { Ge (As); In (Cd); Bi } \\
(\mathrm{Pb})\end{array}$ & 0.006 & 0.006 & 0.09 & 0.02 & 0.02 & 0.3 & ICP-MS, external calibration \\
\hline PT816 & $\begin{array}{l}\text { Weight } 0.5 \mathrm{~g} \text { sample. Microwave digestion in closed MW } \\
\text { system with } 5 \mathrm{ml} \mathrm{HNO}+1 \mathrm{ml} \mathrm{H} 2 \mathrm{O} \text {. Transfer to } 50 \mathrm{ml} \text { with } \\
\text { DDW. }\end{array}$ & & 0.06 & 0.01 & 0.07 & 0.45 & 0.05 & 0.5 & $\begin{array}{l}\text { GFAAS AS:Matrix modificator } 10 \mathrm{ul} \mathrm{Pd} 500 \mathrm{ug} / \mathrm{ml} \\
\text { Cd/Pb:matrix modificator } 5 \mathrm{ul} 1 \% \mathrm{NH} 4 \mathrm{H} 2 \mathrm{PO} 4+100 \mathrm{ug} / \mathrm{mg}\end{array}$ \\
\hline PT817 & Microwave digestion & In & 0.002 & 0.02 & 0.02 & 0.002 & 0.03 & 0.04 & ICP-MS \\
\hline PT818 & $\begin{array}{l}\text { Addition of hydrogen peroxide and nitric acid with } \\
\text { subsequent microwave digestion. }\end{array}$ & $\mathrm{In} / \mathrm{Ge} / \mathrm{Ir}$ & & & & 0.046 & 0.021 & 0.267 & ICP-MS \\
\hline PT819 & $\begin{array}{l}\text { Microwave digestion: } 0.5 \mathrm{~g} \text { of sample }+5 \mathrm{~mL} \text { HNO3 } \\
\text { Final volume: } 50 \mathrm{~mL} \text {; Dilution } 1 / 5 ; 1 / 10 \text { or } 1 / 50\end{array}$ & $\begin{array}{l}\text { In for } \mathrm{Pb} \text { and } \mathrm{Cd} \text { in } \\
\text { standard mode; } \mathrm{Sc} \text { for } \\
\mathrm{As} \text { in collision mode } \\
(\mathrm{He})\end{array}$ & & & & & & & ICP-MS \\
\hline PT820 & 'Verassen bij $550^{\circ} \mathrm{C}$. Koken met 2M HCL' ISO 27085:2009 & Beryllium & & 0.075 & 0.1 & & 0.15 & 0.2 & ICP-OES \\
\hline PT821 & & Scandium & 0.1 & 0.01 & 0.05 & 0.2 & 0.02 & 0.1 & ICP-MS \\
\hline
\end{tabular}




\begin{tabular}{|c|c|c|c|c|c|c|c|c|c|}
\hline \multirow{2}{*}{$\begin{array}{l}\text { Lab } \\
\text { PT838 }\end{array}$} & \multirow{2}{*}{$\begin{array}{l}\text { Samples digested in nitric and hydrochloric acid mixture, } \\
\text { then diluted for measurement. Arsenic measured using } \\
\text { collision cell, helium mode. } \square \text { Cadmium and lead in no gas } \\
\text { mode. }\end{array}$} & \multirow{2}{*}{ Internal standard } & \multicolumn{3}{|c|}{ LOD (mg/kg) } & \multicolumn{3}{|c|}{ LOQ (mg/kg) } & \multirow{2}{*}{$\begin{array}{l}\text { Inductively coupled plasma mass spectrometry (ICP- } \\
\text { MS) }\end{array}$} \\
\hline & & & 0.005 & 0.005 & 0.005 & 0.017 & 0.017 & 0.017 & \\
\hline PT839 & & & & & & & & & ICP-MS \\
\hline PT840 & & & & & & & & & \\
\hline PT841 & & $\begin{array}{l}\text { based on NEN-EN-ISO } \\
172941 / 2\end{array}$ & 0.01 & 0.005 & 0.01 & & & & ICP-MS \\
\hline PT842 & centrifugeren / filtreren & $\mathrm{Li}, \mathrm{Sc}, \mathrm{Ge}, \mathrm{Rh}, \mathrm{Ir}, \mathrm{Au}$ & 0.033 & 0.0033 & 0.016 & 0.1 & 0.01 & 0.05 & ICP-MS \\
\hline PT843 & microgolfontsluiting & $\begin{array}{l}\text { Bismut / Lithium / } \\
\text { scandium / Yttrium / } \\
\text { Indium / Tiberium }\end{array}$ & 0.005 & 0.005 & 0.005 & 0.01 & 0.01 & 0.01 & $\begin{array}{l}\text { ICP-MS (Inductief gekoppeld plasma Massa } \\
\text { Spectroscopie). }\end{array}$ \\
\hline PT844 & & & 0.006 & 0.006 & 0.006 & 0.05 & 0.01 & 0.1 & ICP-MS \\
\hline
\end{tabular}




\section{Annex 6 Results}

\begin{tabular}{|c|c|c|c|c|c|}
\hline \multirow[b]{2}{*}{ Labcode } & Arsenic in A & \multicolumn{2}{|c|}{$\begin{array}{c}\text { Cadmium in A } \\
\text { CV: } 0.368 \mathrm{mg} / \mathrm{kg} \\
\text { u: } 0.006 \mathrm{mg} / \mathrm{kg} \\
\sigma_{\mathrm{p}}: 0.068 \mathrm{mg} / \mathrm{kg} \\
\text { robust } 0: 0.022 \mathrm{mg} / \mathrm{kg}\end{array}$} & \multicolumn{2}{|c|}{$\begin{array}{c}\text { Lead in A } \\
\text { CV: } 5.15 \mathrm{mg} / \mathrm{kg} \\
\text { u: } 0.121 \mathrm{mg} / \mathrm{kg} \\
\sigma_{\mathrm{p}}: 0.643 \mathrm{mg} / \mathrm{kg} \\
\text { robust } \sigma: 0.445 \mathrm{mg} / \mathrm{kg}\end{array}$} \\
\hline & Results (mg/kg) & Result(mg/kg) & $\mathbf{z}_{\mathrm{a}}$-score & Result (mg/kg) & $z_{a}$-score \\
\hline PT735 & nd & 0.34 & -0.41 & 5 & -0.23 \\
\hline PT808 & $<0.3$ & 0.37 & 0.03 & 5 & -0.23 \\
\hline PT810 & nd & 0.36 & -0.12 & 5.05 & -0.15 \\
\hline PT811 & 0.081 & 0.359 & -0.13 & 4.74 & -0.63 \\
\hline PT812 & nd & 0.35 & -0.26 & 3.45 & -2.64 \\
\hline PT813 & nd & 0.36 & -0.12 & 4.98 & -0.26 \\
\hline PT814 & nt & detected & & 5.53 & 0.60 \\
\hline PT815 & 0.094 & 0.346 & -0.32 & 5.13 & -0.03 \\
\hline PT816 & detected & 0.412 & 0.64 & 4.976 & -0.27 \\
\hline PT817 & 0.074 & 0.322 & -0.67 & 4.679 & -0.73 \\
\hline PT818 & 0.116 & 0.468 & 1.46 & 6.216 & 1.66 \\
\hline PT819 & detected & 0.357 & -0.16 & 5.38 & 0.36 \\
\hline PT820 & nt & 0.3548 & -0.19 & 5.4666 & 0.50 \\
\hline PT821 & 0.075 & 0.36 & -0.12 & 4.9 & -0.38 \\
\hline PT838 & 0.088 & 0.407 & 0.57 & 5.72 & 0.89 \\
\hline PT839 & 0.087 & 0.372 & 0.06 & 4.89 & -0.40 \\
\hline PT840 & 0.125 & 0.365 & -0.04 & 4.576 & -0.89 \\
\hline PT841 & 0.1 & 0.4 & 0.47 & 5.3 & 0.24 \\
\hline PT842 & $<0.1$ & 0.381 & 0.19 & 5.1 & -0.07 \\
\hline PT843 & 0.1 & 0.4 & 0.47 & 5.75 & 0.94 \\
\hline PT844 & 0.07 & 0.38 & 0.17 & 11.1 & 9.25 \\
\hline \multicolumn{6}{|c|}{ CV consensus value. } \\
\hline \multicolumn{6}{|c|}{ u uncertainty of consensus value. } \\
\hline \multicolumn{6}{|c|}{ nd not detected. } \\
\hline \multicolumn{6}{|c|}{ nt not tested for } \\
\hline * reporte & creening results. & & & & \\
\hline
\end{tabular}




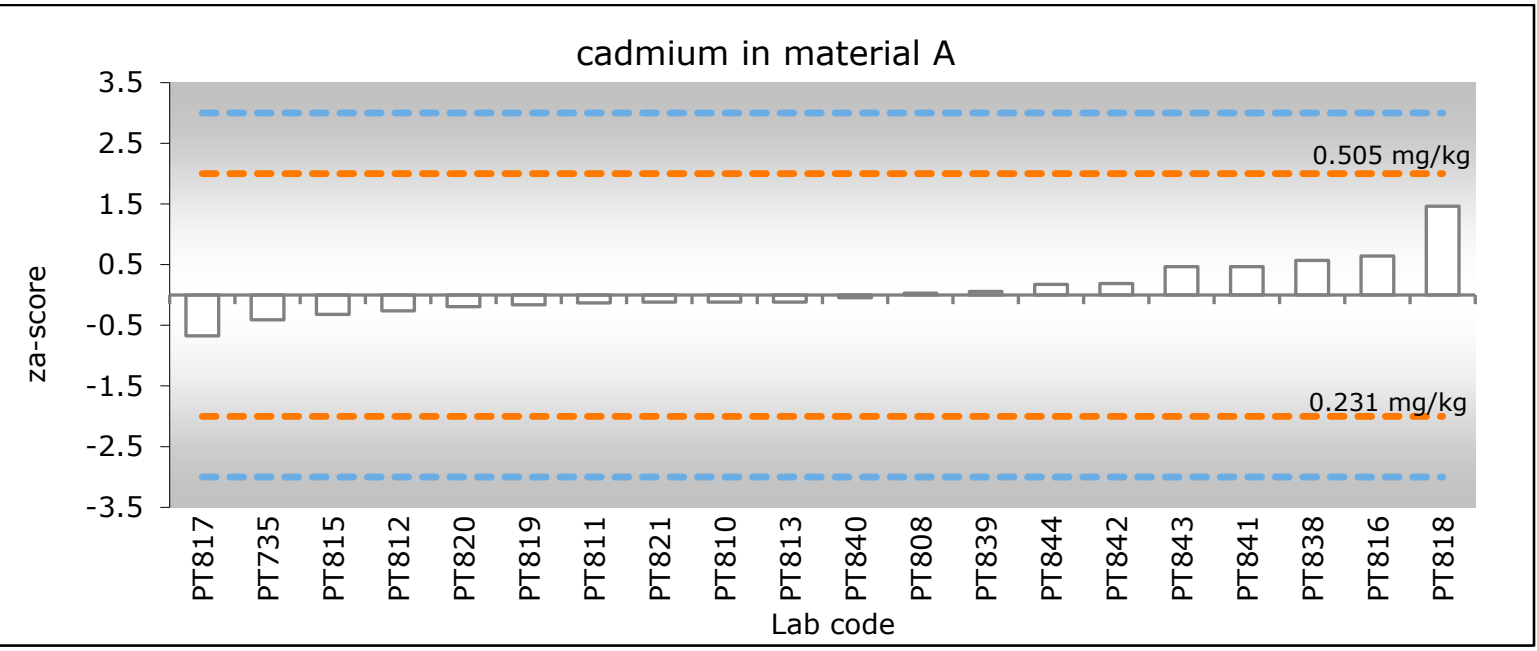

Figure a Graphical representation of the $z_{a}$-scores. The $X \pm 2 \sigma_{P}$ lines (dotted) are calculated according to equation $V$ in $\S 4.4$.

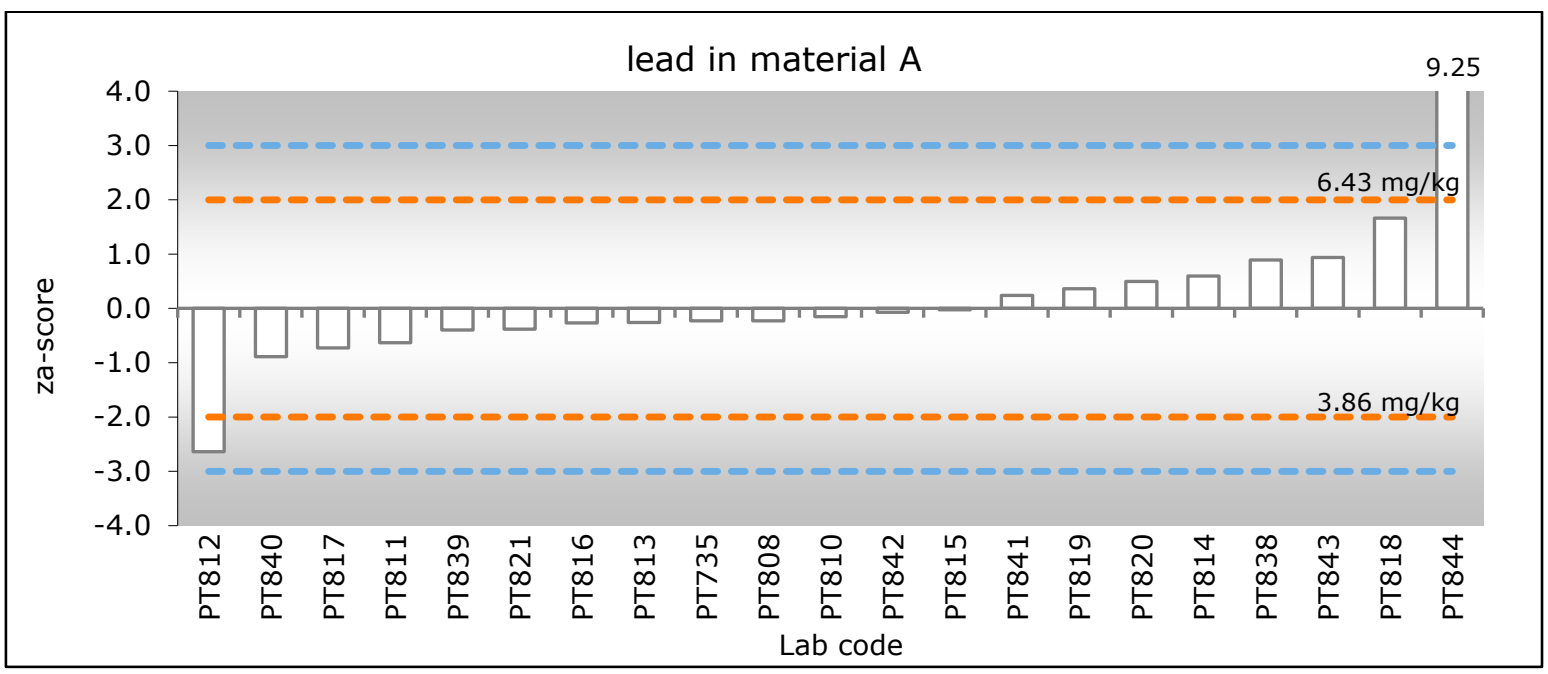

Figure $\boldsymbol{b} \quad$ Graphical representation of the $z_{a}$-scores. The $X \pm 2 \sigma_{P}$ lines (dotted) are calculated according to equation $V$ in $\$ 4.4$. 


\begin{tabular}{|c|c|c|c|c|c|}
\hline \multirow[b]{6}{*}{ Labcode } & \multirow{5}{*}{ Lead in $B$} & \multicolumn{2}{|c|}{ Cadmium in B } & \multicolumn{2}{|c|}{ Arsenic in B } \\
\hline & & \multirow{2}{*}{\multicolumn{2}{|c|}{$\begin{array}{l}\mathrm{CV}: 0.623 \mathrm{mg} / \mathrm{kg} \\
\text { u: } 0.012 \mathrm{mg} / \mathrm{kg}\end{array}$}} & \multicolumn{2}{|c|}{ CV: $3.01 \mathrm{mg} / \mathrm{kg}$} \\
\hline & & & & \multicolumn{2}{|c|}{ u: $0.087 \mathrm{mg} / \mathrm{kg}$} \\
\hline & & \multirow{2}{*}{\multicolumn{2}{|c|}{$\begin{array}{c}\sigma_{\mathrm{p}}: 0.107 \mathrm{mg} / \mathrm{kg} \\
\text { robust } \sigma: 0.043 \mathrm{mg} / \mathrm{kg}\end{array}$}} & \multirow{2}{*}{\multicolumn{2}{|c|}{$\begin{array}{l}\sigma_{\mathrm{p}}: 0.407 \mathrm{mg} / \mathrm{kg} \\
\text { robust } \sigma: 0.305 \mathrm{mg} / \mathrm{kg}\end{array}$}} \\
\hline & & & & & \\
\hline & Results (mg/kg) & Results(mg/kg) & $\mathrm{Z}_{\mathrm{a}}$-score & Results (mg/kg) & $z_{a}$-score \\
\hline PT735 & nd & 0.64 & 0.16 & 3.1 & 0.23 \\
\hline PT808 & $<0.3$ & 0.68 & 0.54 & 3 & -0.01 \\
\hline PT810 & nd & 0.61 & -0.12 & 3.05 & 0.11 \\
\hline PT811 & nd & 0.607 & -0.15 & 2.99 & -0.04 \\
\hline PT812 & 0.062 & 0.61 & -0.12 & 2.64 & -0.90 \\
\hline PT813 & nd & 0.59 & -0.30 & 2.81 & -0.48 \\
\hline PT814 & nd & 0.669 & 0.43 & nt & \\
\hline РT815 & $<0.3$ & 0.569 & -0.50 & 2.99 & -0.04 \\
\hline PT816 & detected & 0.643 & 0.19 & 1.046 & -4.81 \\
\hline PT817 & 0.06 & 0.525 & -0.91 & 2.846 & -0.39 \\
\hline PT818 & 0.086 & 0.781 & 1.48 & 4.097 & 2.68 \\
\hline РT819 & 0.075 & 0.548 & -0.70 & 2.5 & -1.24 \\
\hline PT820 & 0.0145 & 0.5962 & -0.25 & nt & \\
\hline PT821 & 0.068 & 0.59 & -0.30 & 2.98 & -0.06 \\
\hline РТ838 & 0.078 & 0.68 & 0.54 & 3.19 & 0.45 \\
\hline РT839 & 0.067 & 0.624 & 0.01 & 3.028 & 0.05 \\
\hline PT840 & 0.072 & 0.611 & -0.11 & 3.287 & 0.69 \\
\hline PT841 & 0.07 & 0.69 & 0.63 & 3.4 & 0.97 \\
\hline РT842 & 0.055 & 0.631 & 0.08 & 3.52 & 1.26 \\
\hline РT843 & 0.07 & 0.67 & 0.44 & 3.12 & 0.28 \\
\hline РT844 & 0.354 & 0.615 & -0.07 & 2.68 & -0.80 \\
\hline
\end{tabular}

CV consensus value.

u uncertainty of consensus value.

nd not detected.

* reported only screening results. 


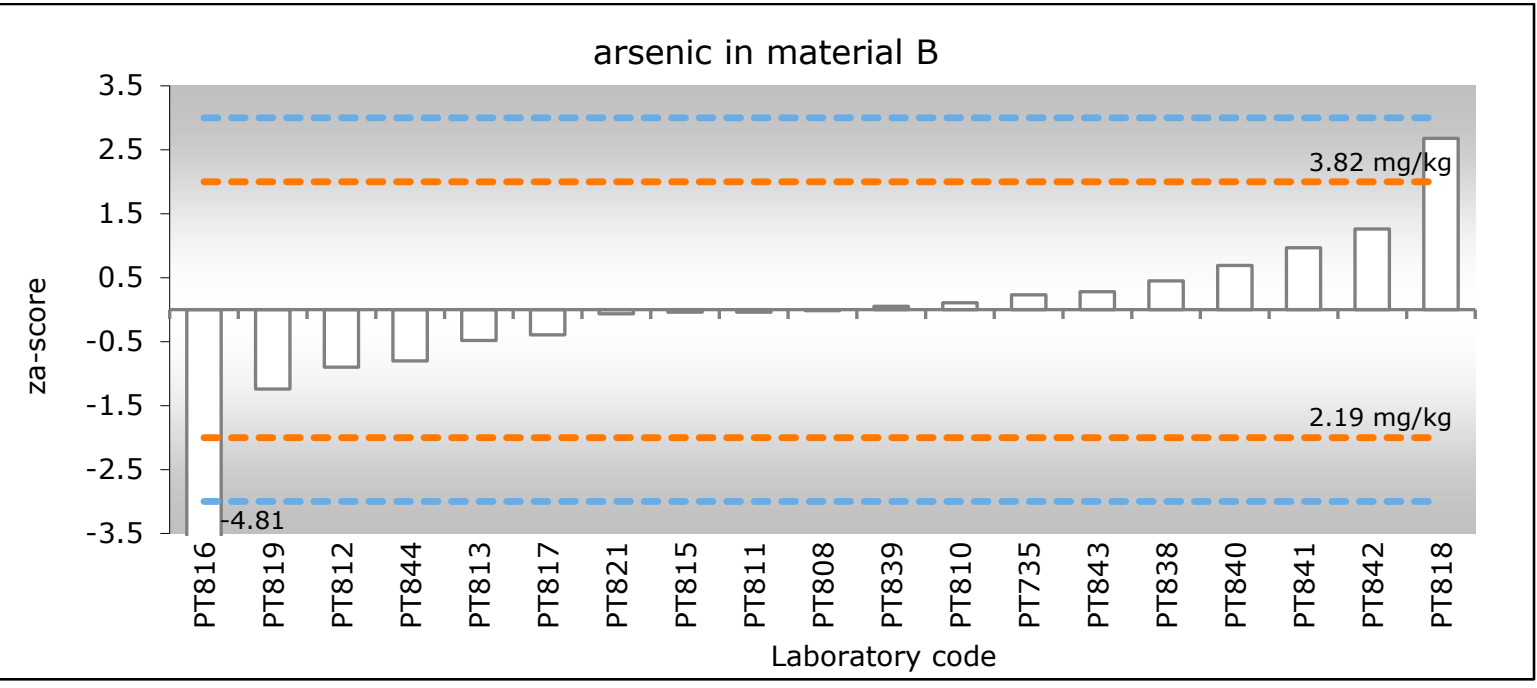

Figure $\boldsymbol{c} \quad$ Graphical representation of the $z_{a}$-scores. The $X \pm 2 \sigma_{P}$ lines (dotted) are calculated according to equation $V$ in $\$ 4.4$.

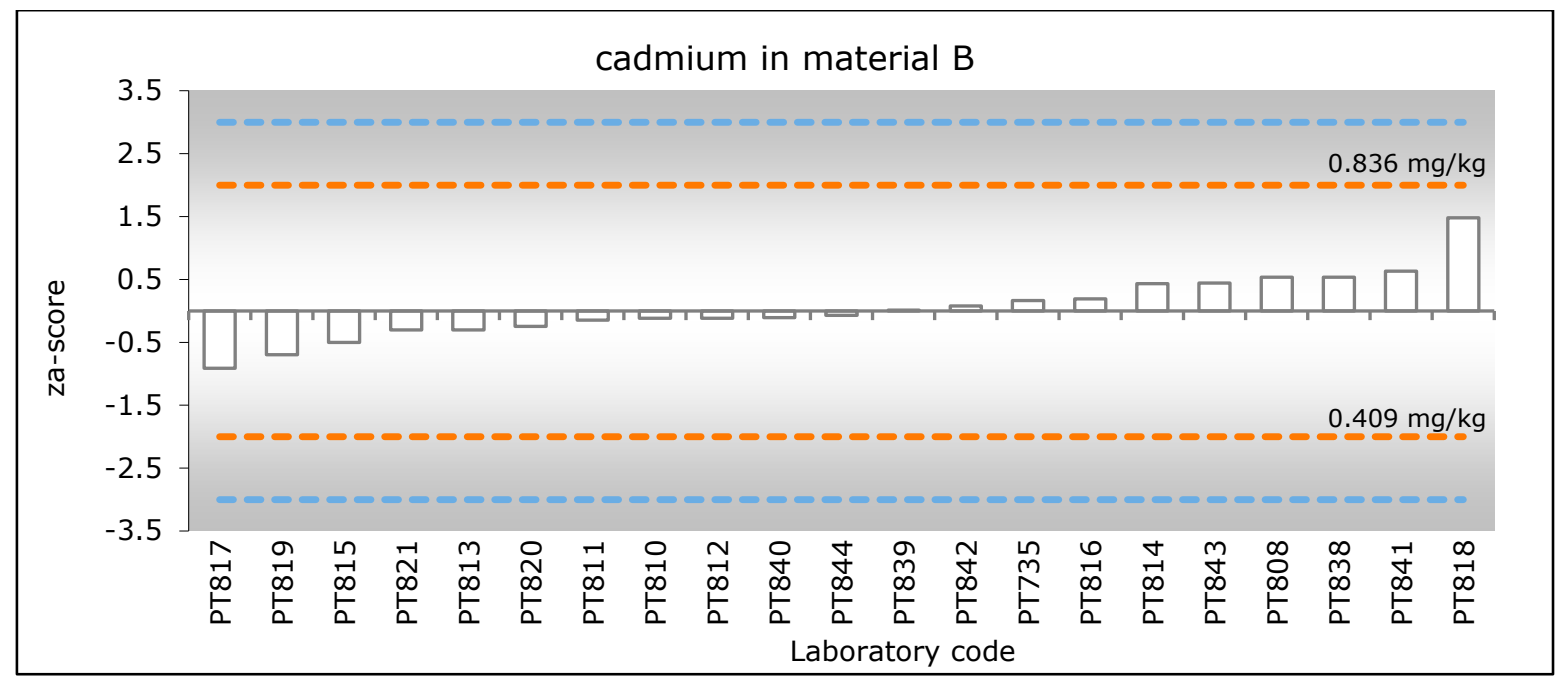

Figure d Graphical representation of the $z_{a}$-scores. The $X \pm 2 \sigma_{P}$ lines (dotted) are calculated according to equation $V$ in $\$ 4.4$. 


\section{Annex 7 Overview performance per laboratory}

\begin{tabular}{lll} 
Laboratory code & \# of z-scores & Remarks \\
PT735 & 4 & Optimal performance \\
\hline PT808 & 4 & Optimal performance \\
\hline PT810 & 4 & Optimal performance \\
\hline PT811 & 4 & Optimal performance \\
\hline PT812 & 4 & 1 questionable z-score \\
\hline PT813 & 4 & Optimal performance \\
\hline PT814 & 3 & Optimal performance \\
\hline PT815 & 4 & Optimal performance \\
\hline PT816 & 4 & 1 unsatisfactory z-score \\
\hline PT817 & 4 & Optimal performance \\
\hline PT818 & 4 & 1 questionable z-score \\
\hline PT819 & 4 & Optimal performance \\
\hline PT820 & 3 & Optimal performance \\
\hline PT821 & 4 & Optimal performance \\
\hline PT838 & 4 & Optimal performance \\
\hline PT839 & 4 & Optimal performance \\
\hline PT840 & 4 & Optimal performance \\
\hline PT841 & 4 & Optimal performance \\
\hline PT842 & 4 & Optimal performance \\
\hline PT843 & 4 & Optimal performance \\
\hline PT844 & 4 & 1 unsatisfactory z-score \\
\hline & & \\
\hline & & \\
\hline
\end{tabular}


RIKILT Wageningen University \& Research P.O. Box 230

6700 AE Wageningen

The Netherlands

$\mathrm{T}+31(0) 317480256$

www.wur.eu/rikilt

RIKILT report 2016.015
The mission of Wageningen University and Research is "To explore the potential of nature to improve the quality of life". Under the banner Wageningen University \& Research, Wageningen University and the specialised research institutes of the Wageningen Research Foundation have joined forces in contributing to finding solutions to important questions in the domain of healthy food and living environment. With its roughly 30 branches, 5,000 employees and 10,000 students, Wageningen University \& Research is one of the leading organisations in its domain. The unique Wageningen approach lies in its integrated approach to issues and the collaboration between different disciplines. 



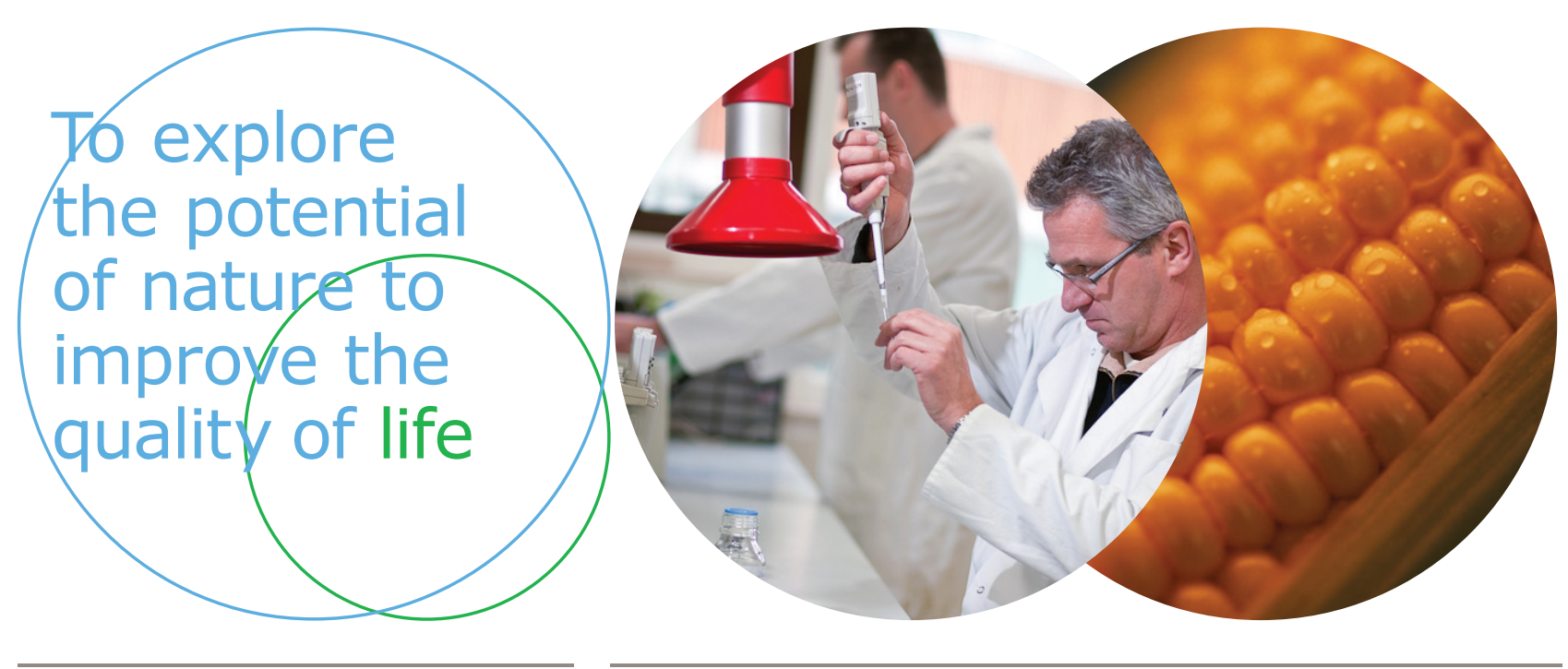

RIKILT Wageningen University \& Research P.O. Box 230

6700 AE Wageningen

The Netherlands

T +31 (0)317480256

www.wur.eu/rikilt

Report 2016.015
The mission of Wageningen University and Research is "To explore the potential of nature to improve the quality of life". Under the banner Wageningen University \& Research, Wageningen University and the specialised research institutes of the Wageningen Research Foundation have joined forces in contributing to inding solutions to important questions in the domain of healthy food and living environment. With its roughly 30 branches, 5,000 employees and 10,000 students, Wageningen University \& Research is one of the leading organisations in its domain. The unique Wageningen approach lies in its integrated approach to issues and the collaboration between different disciplines. 